\title{
EFEKTIVITAS BAHAN AJAR E-MODUL INTERAKTIF BERBASIS ANDROID UNTUK PENINGKATAN PEMAHAMAN KONSEP LINGKARAN KELAS VI SD
}

\author{
Makmun Murod \\ Magister Pendidikan Dasar, Universitas Muria Kudus \\ makmunmurod.010@gmail.com \\ Slamet Utomo \\ Magister Pendidikan Dasar, Universitas Muria Kudus \\ slamet.utomo@umk.ac.id \\ Sri Utaminingsih \\ Magister Pendidikan Dasar, Universitas Muria Kudus \\ sri.utaminingsib@umk.ac.id
}

\begin{abstract}
Abstrak:
Latar belakang masalah dalam penelitian ini adalah rendahnya hasil belajar siswa kelas VI pada pembelajaran Matematika materi konsep lingkaran. Faktor-faktor yang menyebabkan hasil belajar Matematika masih rendah salah satunya adalah masih kurangnya penggunaan bahan ajar yang menarik dan menunjang proses pembelajaran. Tujuan penelitian ini adalah menganalisis efektivitas bahan ajar Matematika e-modul interaktif berbasis android untuk meningkatkan pemahaman konsep lingkaran kelas VI Sekolah Dasar di Kabupaten Demak. Teknik pengumpulan data yang digunakan adalah observasi, angket dan tes tetulis. Instrumen penelitian berupa tes. Sampel penelitian ini dilakukan dengan purpose sampling. Analisis data meliputi deskripsi data, uji prasyarat analisis, dan uji hipotesis dengan menggunakan uji t. Hasil penelitian adalah bahan ajar Matematika e-modul interaktif berbasis android cukup efektif untuk meningkatkan pemahaman konsep lingkaran kelas VI tentang konsep lingkaran dengan nilai t-hitung 30,926 sedangkan t-tabel sebesar 1,9765 maka t-hitung $>$ t-tabel atau $30.926>1,9765$.
\end{abstract}

Kata Kunci: e-modul interaktif, hasil belajar, Matematika

\begin{abstract}
:
The background of this research is the low level of grade VI students' mathematics learning result in circle concept material. One of the factors that causes mathematics learning outcomes is still low, one of which is the lack of use of interesting teaching materials that support the learning process. The purpose of this study was to analyze the effectiveness of the interactive mathematics e-module teaching materials based on android to improve understanding of the concept of circle VI grade elementary schools in Demak. Regency. The data collection techniques used were observation, questionnaires and written tests. The research instrument was a test. The sample of this research was conducted by using purposive sampling. Data Analysis of data includes data descriptions, analysis prerequisite tests, and hypothesis testing using the t test. The result of this research is that the interactive e-module mathematics teaching material based on android is quite effective in increasing the understanding of class VI students about the circle concept of the t-count value of 30.926 while the $t$-table is 1.9765 , then $t$-count $>$ t-table or $30.926>1.9765$.
\end{abstract}

Keywords: Interactive e-modules, Learning outcomes, Mathematics

FENOMENA, Vol. 20 No. 2 (Juli - Desember 2021) | 219 


\section{PENDAHULUAN}

Dalam konteks kegiatan belajar mengajar (KBM), guru merupakan seorang pemimpin (leader), seorang pengelola atau manajer pembelajaran (learning manager); yang memimpin dan mengelola kelas [sebagai lingkungan belajar serta merupakan aspek dari lingkungan sekolah yang perlu diorganisasi $]^{1}$. Guru sebagai pelaku utama yang bertanggung jawab terhadap keberhasilan pendidikan, karena guru sebagai tenaga pendidik yang berhubungan langsung dengan peserta didik. Baik atau buruknya proses pembelajaran dan tercapai atau tidaknya tujuan pembelajaran sangat bergantung pada kompetensi yang dimiliki guru khususnya kompetensi pedagogik.

Secara umum pelaksanaan pembelajaran pada kurikulum 2013 belum berjalan secara optimal. Masih ditemukan beberapa permasalahan, misalnya pembelajaran yang masih berpusat pada guru, kurangnya kesempatan siswa untuk memperoleh pengalaman langsung baik mengamati, menanya, mencoba, mengolah informasi, dan mengkomunikasikan, pembelajaran yang diberikan guru lebih didominasi ceramah, sehingga terkesan monoton, dan sebagian siswa belum aktif dalam pembelajaran ${ }^{2}$. Kondisi seperti ini bertolak belakang dengan peran guru pada abad 21, yakni: "Teachers play a significant role in belping students develop $21^{\text {st }}$ century skill by applying methods that increase student's abilities"3. Guru seharusnya memiliki upaya kreatif dan inovatif, serta menyiapkan strategi pembelajaran modern, dan memanfaatkan teknologi, sehingga dapat meningkatkan partisipasi siswa dalam pembelajaran ${ }^{4}$.

Kemampuan pedagogik seorang guru dalam menyampaikan materi belajar tidak hanya mengandalkan sumber atau bahan ajar yang sudah ada. Penggunaan bahan ajar merupakan salah satu faktor keberhasilan proses pembelajaran. Guru hendaknya kreatif mengembangkan bahan ajar sebagai upaya untuk menghadirkan pembelajaran yang menarik dan bermakna. Pengembangan bahan ajar yang relevan terhadap materi ajar dan sesuai dengan kebutuhan peserta didik tentu akan menciptakan pembelajaran yang aktif, inovatif, efektif dan menyenangkan sehingga tujuan pembelajaran yang diharapkan dapat tercapai dengan maksimal dan memuaskan ${ }^{5}$.

Kondisi tersebut juga tergambar pada hasil pengamatan/observasi langsung di SD Negeri Harjowinangun 2 Dempet Demak pada kelas 6A dan 6B mulai tanggal 1-5 Oktober 2019, bahan ajar yang digunakan guru dan siswa adalah BSE Matematika KTSP 2006 dan LKS, sekolah belum

\footnotetext{
${ }^{1}$ Novan Ardy Wiyani, Manajemen Kelas (Yogyakarta: Ar-Ruzz Media, 2013), 43-44.

2 Desyandri \& Dori Vernanda, Pengembangan Bahan Ajar Tematik Terpadu di Kelas V Sekolah Dasar Menggunakan Identifikasi Masalah, dalam Seminar Nasional HDPGSDI Wilayah 4, 2017, 163-174

${ }^{3}$ Halah Ahamed Alismail \& Patrick McGuire, 21 ${ }^{\text {st }}$ Century Standards and Curriculum: Current Research and Practice. Journal of Education and Practice, 6(6) 2015, 150-155.

4 Shih-Fen Cheng, Application of Creative Teaching, Hu Li Za Zhi The Journal of Nursing, 65(6) 2018, 4, https://doi.org/10.6224/JN.201812 65(6).01.

5 Andi Prastowo, Panduan kreatif membuat bahan ajar inovatif: Menciptakan metode pembelajaran yang menarik dan menyenangkan (Yogyakarta: DIVA Press, 2012), 5.
} 
memiliki buku paket Matematika kurikulum 2013 yang diterbitkan oleh Depdiknas, dalam proses pembelajaran guru kurang memberi motivasi belajar kepada siswa. Hal ini kurang sesuai dengan prinsip pengembangan bahan ajar. Daryanto dan Dwicahyono (2014:172) menjelaskan bahwa prinsip pengembangan bahan ajar di antaranya bahan ajar yang disajikan mulai dari hal yang mudah untuk memahami hal yang sulit, dari yang konkrit untuk memahami yang abstrak, dan motivasi belajar yang tinggi merupakan salah satu faktor penentu keberhasilan belajar ${ }^{6}$.

Bahan ajar yang digunakan oleh guru dan siswa masih kurang merangsang siswa untuk aktif, masih kurang menarik, kurang menyenangkan, masih kurang holistik, dan kurang autentik. Hal ini juga kurang sesuai dengan karakteristik bahan ajar menurut Prastowo (2014:142), bahan ajar memiliki beberapa karakteristik diantaranya: (1) aktif; (2) menarik atau menyenangkan; (3) holistik; dan (4) autentik (memberikan pengalaman langsung) ${ }^{7}$

Berdasarkan hasil wawancara terhadap salah satu guru kelas VI menyatakan bahwa ketika pembelajaran berlangsung siswa kurang antusias dan kesulitan dalam memahami meteri pelajaran yang membutuhkan visualisasi ataupun bersifat abstrak seperti yang terdapat pada materi lingkaran. Hal tersebut terlihat dari hasil belajar siswa rendah. Berdasarkan hasil nilai Rapor semester I tahun pelajaran 2019/2020 yang di peroleh dari guru Matematika kelas VI nilai rata-rata yang diperoleh 63\% dengan Kriteria Ketuntasan Minimal (KKM) yaitu 65\%. Dari persentase ketuntasan klasikal tersebut menunjukkan bahwa hasil belajar siswa di bawah KKM. Pemecahan masalah dalam materi lingkaran diperlukan visualisasi, sehingga siswa dapat mengkomunikasikan kembali sebuah konsep yang telah dipelajarinya ${ }^{8}$.

Salah satu materi pada mata pelajaran Matematika adalah lingkaran. Karakteristik materi lingkaran tersebut membutuhkan tingkat pemahaman konsep yang lebih tinggi dibandingkan dengan materi lainnya. Materi tersebut bersifat visual yang menuntut siswa mampu berfikir kreatif dan mempelajari obyek-obyek abstrak di dalamnya. Oleh karena itu, tolok ukur berhasilnya pembelajaran Matematika dapat ditunjukkan jika siswa mampu memahami suatu konsep serta didukung dengan bahan ajar yang interaktif. Namun, selama ini bahan ajar yang digunakan, dikemas dalam bentuk tidak interaktif dan kurang lengkap, sehingga tidak dapat merangsang proses berfikir siswa. Untuk itu diperlukan sebuah bahan ajar yang mampu menjelaskan materi secara lebih rinci, memvisualisasikan materi yang abstrak, melatih siswa untuk berfikir kreatif serta mampu

\footnotetext{
${ }^{6}$ Daryanto dan Dwicahyono, Pengembangan Perangkat Pembelajaran. (Silabus, RPP, PHB Bahan Ajar). (Yogyakarta: Gava Media, 2014) 172.

7 Andi Prastowo, Pengembangan Bahan Ajar Tematik: Tinjauan Teoretis dan Praktis (Yogyakarta: DIVA Press, 2014), 142.

${ }^{8}$ R. Kariadinata, Kemampuan visualisasi geometri spasial siswa Madrasah Aliyah Negeri kelas X melalui sioftware pembelajaran mandiri, Jurnal Edukasi Matematika, 1 (2) 2010.
} 
memecahkan masalah. Salah satu bahan ajar yang dirasa dapat membantu siswa maupun guru dalam mengatasi masalah tersebut yaitu modul interaktif.

Modul interaktif merupakan jenis bahan ajar yang memadukan teks materi dengan pendukung media lainnya seperti terdapatnya gambar, animasi, video, dan memudahkan navigasi. Modul interaktif yang akan dikembangkan dalam penelitian ini dikemas dalam bentuk digital. Karakteristik media yang demikian dapat membantu siswa dalam memahami konsep Matematika khususnya materi lingkaran. Penggunaan modul interaktif yang berbasis digital belum banyak digunakan oleh guru.

Modul interaktif yang akan dikembangkan, dilengkapi dengan berbagai konten pembelajaran seperti teks, gambar, animasi, dan video yang dapat digunakan sebagai sumber belajar yang tepat untuk materi lingkaran. Materi lingkaran dapat dipelajari dengan mudah karena terdapat kontenkonten pembelajaran tersebut. Melalui bahan ajar tersebut diduga dapat memudahkan siswa dalam memahami konsep Matematika khususnya materi lingkaran. Melalui modul tersebut, tentunya siswa akan terbantu dalam menguasai kompetensi dari materi lingkaran.

Penggunaan bahan ajar berupa e-modul interaktif ini dapat dibaca pada komputer maupun laptop, merupakan salah satu aternatif dalam pembelajaran Matematika khususnya materi yang membutuhkan visualisasi. Bahan ajar interaktif ini dikemas dalam bentuk digital, sehingga bahan ajar ini bersifat lebih praktis dan memiliki konten-konten pembelajaran yang memudahkan siswa belajar dibandingkan dengan bahan ajar lainnya (modul cetak, LKS dan buku). Konten-konten tersebut berupa teks, gambar, animasi dan video yang dijadikan dalam satu file. Bahan ajar interaktif ini bersifat lengkap, praktis, dan memudahkan siswa mempelajari konsep Matematika kapan pun dan dimana pun siswa berada dengan belajar mandiri.

\section{TINJAUAN PUSTAKA}

Menurut Hamdani (2011:120) bahan ajar adalah segala bentuk bahan atau materi yang disusun secara sistematis yang digunakan untuk membantu guru atau instruktur dalam melaksanakan kegiatan belajar mengajar sehingga tercipta lingkungan atau suasana yang memungkinkan siswa untuk belajar'. Jenis bahan ajar yang dikemukakan oleh para ahli memiliki kesamaan yaitu terdiri dari bahan ajar cetak dan non cetak. Sehingga pada penelitian ini akan mengembangkan jenis bahan ajar yang mengkombinasikan antara bahan ajar cetak (modul) dengan bahan ajar noncetak (animasi, video, dan gambar) atau bahan ajar multimedia interaktif yang dikemas dalam bentuk

\footnotetext{
${ }^{9}$ Hamdani, Strategi Belajar Mengajar (Bandung: Pustaka Setia, 2011), 120.
} 
aplikasi android yang disebut Bahan Ajar Interaktif. Bahan ajar interaktif menurut Guidelines for Bibliographic Description of Interaktif Multimedia, P. 1 (Majid, 2009: 181) yaitu kombinasi dari dua atau lebih media (teks, gambar, video, dan animasi) yang dapat dikendalikan oleh pengguna ${ }^{10}$.

Menurut Yudhi Munadi (2013:98) modul merupakan bahan belajar yang dapat digunakan oleh peserta didik untuk belajar secara mandiri dengan bantuan seminimal mungkin dari orang lain. Modul merupakan paket belajar mandiri yang meliputi serangkaian pengalaman belajar yang dirancang secara sistematis untuk membantu peserta didik mencapai tujuan belajar. Komponenkomponen modul adalah petunjuk/pedoman guru, lembar kegiatan peserta didik, lembar kerja, kunci jawaban lembar kerja, lembar tes, serta kunci jawaban lembar tes. Sehingga peserta didik benar-benar belajar secara mandiri tanpa didampingi oleh guru ${ }^{11}$.

Modul elektronik atau e-modul adalah sebuah bentuk penyajian bahan belajar mandiri yang disusun secara sistematis ke dalam unit pembelajaran terkecil untuk mencapai tujuan pembelajaran tertentu yang disajikan ke dalam format elektronik yang di dalamnya terdapat animasi, audio, navigasi yang membuat pengguna lebih interaktif dengan program ${ }^{12}$. Pada dasarnya modul elektronik dalam struktur penulisannya mengadaptasi format, karakteristik, dan bagian-bagian yang terdapat pada modul cetak pada umumnya.

Pengembangan bahan ajar interaktif berupa modul pembelajaran dapat mengatasi minimnya bahan ajar yang digunakan oleh guru maupun siswa. Bahan ajar merupakan sumber belajar yang berisi topik-topik tertentu, dapat berupa cetak maupun elektronik (digital). Pada penelitian ini akan mengembangkan bahan ajar interaktif berupa digital yang dapat menampilkan materi yang berbentuk visual yang dilengkapi dengan teks, gambar, animasi, dan video.

\section{METODOLOGI}

Desain penelitian ini menggunakan metode eksperimen nonrandomized subject pre-test post-test control group design, dimana terdapat kelompok eksperimen dan kelompok kontrol yang tidak dipilih secara random ${ }^{13}$. Dalam desain ini uji lapangan terbatas dilakukan di SDN Kramat 1 sebagai kelas kontrol dan SDN Kramat 3 sebagai kelas eksperimen. Uji coba lapangan luas dilaksanakan pada semester 2 tahun ajaran 2020/2021 pada SDN Harjowinangun 1, SDN Sidomulyo 1, SDN Sidomulyo 3, SDN Kebonsari 1, SDN Harjowinangun 2, SDN Gempoldenok. Pemilihan sampling dalam penelitian ini dengan teknik cluster sampling. Teknik pengumpulan data yang digunakan adalah

10 Abdul Majid, Perencanaan Pembelajaran Mengembangkan Kompetensi Guru (Bandung: PT Remaja Rosdakarya, 2009), 181.

11 Yudhi Munadi, Media Pembelajaran: Sebuah Pendekatan Baru (Jakarta: Referensi, 2013), 98.

12 Sugianto, Modul Virtual: Multimedia Flipbook Dasar Teknik Digital. INVOTEC, Volume IX, No. 2, (Agustus 2013), 101-116. https:// ejournal.upi.edu/ index.php/invotec/article/viewFile/4860/3399

13 Sugiyono, Metode Penelitian dan Pengembangan (Research and Development) (Bandung: Alfabeta, 2016), 116. 
observasi, angket dan tes tetulis. Analisis data meliputi deskripsi data, uji prasyarat analisis, dan uji hipotesis dengan menggunakan uji $\mathrm{t}$.

\section{PEMBAHASAN}

\section{Uji Coba Terbatas}

\section{a. Analisis Deskriptif}

Uji coba terbatas dilakukan pada kelas kontrol yaitu SD Kramat 1 dengan jumlah 29 siswa kelas VI dengan pembelajaran secara konvensinal, dan kelas eksperimen yaitu SD Kramat 3 yang berjumlah 31 siswa. Hasil analisis deskriptif hasil belajar Matematika diperoleh dengan pembelajaran menggunakan e-modul interaktif berbasis android sebagaimana tabel berikut.

Tabel 1. Deskripsi data uji coba terbatas

\begin{tabular}{|c|c|c|c|c|c|}
\hline \multicolumn{6}{|c|}{ Statistics } \\
\hline & & $\begin{array}{l}\text { Nilai Pre-test } \\
\text { Kelas Kontrol }\end{array}$ & $\begin{array}{l}\text { Nilai Pre-test Ke- } \\
\text { las Eksperimen }\end{array}$ & $\begin{array}{l}\text { Nilai Post-test } \\
\text { Kelas Kontrol }\end{array}$ & $\begin{array}{c}\text { NIlai Post-test Ke- } \\
\text { las Eksperimen }\end{array}$ \\
\hline \multirow{2}{*}{$\mathrm{N}$} & Valid & 29 & 31 & 29 & 31 \\
\hline & Missing & 117 & 115 & 117 & 115 \\
\hline \multicolumn{2}{|c|}{ Mean } & 42.10 & 46.65 & 60.48 & 76.48 \\
\hline \multicolumn{2}{|c|}{ Median } & 40.00 & 47.00 & 60.00 & 73.00 \\
\hline \multicolumn{2}{|c|}{ Mode } & 40 & 53 & 67 & 73 \\
\hline \multicolumn{2}{|c|}{ Minimum } & 20 & 20 & 33 & 53 \\
\hline \multicolumn{2}{|c|}{ Maximum } & 67 & 67 & 80 & 93 \\
\hline \multicolumn{2}{|c|}{ Sum } & 1221 & 1446 & 1754 & 2371 \\
\hline
\end{tabular}

Dari hasil analisis deskriptif diperoleh gambaran bahwa nilai rata-rata siswa pada pretest Matematika materi konsep lingkaran adalah hampir sama, artinya bahwa kemampuan rata-rata siswa kelas kontrol dan kelas eksperimen mempunyai kemampuan yang hampir sama dan tidak ada yang menonjol. Selain itu untuk nilai rata-rata pada kelas kontrol dan kelas eksperimen masih di bawah KKM.

\section{b. Uji t}

Pengujian hipotesis dengan bantuan SPSS adalah Independent Sample T Test. Independent Sample $T$ Test digunakan untuk menguji signifikansi beda rata-rata dua kelompok. Uji t pada skala terbatas dapat dilihat pada tabel berikut.

Tabel 2. Uji t uji coba terbatas

Group Statistics

\begin{tabular}{clcccc}
\hline \multicolumn{1}{c}{ SD } & N & Mean & Std. Deviation & Std. Error Mean \\
\hline Nilai Post-test & $\begin{array}{l}\text { Kelas Eksperimen } \\
\text { (SDN Kramat 3) }\end{array}$ & 31 & 76.48 & 8.805 & 1.581 \\
Matematika & $\begin{array}{l}\text { Kelas Kontrol } \\
\text { (SDN Kramat 1) }\end{array}$ & 29 & 60.48 & 10.706 & 1.988 \\
\hline
\end{tabular}


Independent Samples Test

\begin{tabular}{|c|c|c|c|c|c|c|c|c|c|c|}
\hline & & $\begin{array}{r}\text { Leve } \\
\text { Tes } \\
\text { Equa } \\
\text { Varis }\end{array}$ & $\begin{array}{l}\text { e's } \\
\text { for } \\
\text { y of } \\
\text { ices }\end{array}$ & \multicolumn{7}{|c|}{ t-test for Equality of Means } \\
\hline & & \multirow[t]{2}{*}{$\mathrm{F}$} & \multirow[t]{2}{*}{ Sig. } & \multirow[t]{2}{*}{$\mathrm{t}$} & \multirow[t]{2}{*}{ df } & \multirow{2}{*}{$\begin{array}{l}\text { Sig. } \\
(2- \\
\text { tailed })\end{array}$} & \multirow[t]{2}{*}{$\begin{array}{l}\text { Mean Dif- } \\
\text { ference }\end{array}$} & \multirow[t]{2}{*}{$\begin{array}{l}\text { Std. Error } \\
\text { Difference }\end{array}$} & \multicolumn{2}{|c|}{$\begin{array}{l}95 \% \text { Confidence } \\
\text { Interval of the } \\
\text { Difference }\end{array}$} \\
\hline & & & & & & & & & Lower & Upper \\
\hline \multirow{2}{*}{$\begin{array}{l}\text { Nilai } \\
\text { Post- } \\
\text { test }\end{array}$} & $\begin{array}{c}\text { Equal } \\
\text { variances } \\
\text { assumed }\end{array}$ & 1.854 & .179 & 6.340 & 58 & .000 & 16.001 & 2.524 & 10.949 & 21.053 \\
\hline & $\begin{array}{l}\text { Equal } \\
\text { variances } \\
\text { not as- } \\
\text { sumed }\end{array}$ & & & 6.299 & 54.339 & .000 & 16.001 & 2.540 & 10.909 & 21.093 \\
\hline
\end{tabular}

Berdasarkan tabel Independent Samples Test menunjukan Nilai Sig. (2-tailed) sebesar 000, maka sig hitung $<$ taraf signifikansi $(000<0,05)$. Nilai t-hitung sebesar 6,340 Nilai t-tabel dengan df $=58$ sebesar 2,0017 maka nilai t-hitung $>$ t-tabel $(6,340>2,0017)$. Sehingga Ho ditolak dan Ha diterima karena Sig. (2-tailed) < 0,05; dan t-hitung $>$ t-tabel. Artinya terdapat peningkatan pemahaman siswa kelas VI tentang konsep lingkaran dengan pembelajaran menggunakan emodul interaktif berbasis android.

\section{c. Uji N Gain}

Hasil uji gain dilakukan dengan bantuan SPSS. Hasil uji N Gain pada data hasil uji coba produk secara luas dapat dilihat pada tabel berikut.

Tabel 3. Hasil uji N-Gain uji coba terbatas

\begin{tabular}{clll}
\hline No & \multicolumn{1}{c}{ Nilai } & \multicolumn{1}{c}{ Kelas Eksperimen } & \multicolumn{1}{c}{ Kelas Kontrol } \\
\hline 1 & N-Gain & 0,541603 & 0,2829 \\
2 & Kriteria & Sedang & Rendah \\
3 & N-Gain \% & 54.1603 & 28.2933 \\
4 & Tafsiran & Cukup efektif & Tidak efektif \\
\hline
\end{tabular}

Berdasarkan data tersebut, hasil perhitungan Gain adalah sebagai berikut:

1) Kelas Eksperimen

Nilai N-Gain sebesar 0,541603 diinterprestasikan dalam katagori sedang dalam rentang $0,3<\mathrm{g}<0,7$. Artinya bahwa terdapat peningkatan pemahaman siswa kelas VI tentang konsep lingkaran dengan kategori sedang. Nilai N-Gain \% sebesar 54,1603 yang ditafsirkan dalam katagori cukup efektif. Artinya bahwa penggunaan e-modul interaktif berbasis android cukup efektif digunakan untuk meningkatkan pemahaman siswa kelas VI tentang konsep lingkaran.

2) Kelas Kontrol 
Nilai N-Gain sebesar 0,2958 yang diinterprestasikan dalam katagori rendah dalam rentang $\mathrm{g}<0,3$. Artinya bahwa peningkatan pemahaman siswa kelas VI tentang konsep lingkaran rendah. Nilai N-Gain \% sebesar 28.2933 yang ditafsirkan dalam katagori tidak efektif. Artinya bahwa pembelajaran Matematika secara konvensional tanpa e-modul interaktif berbasis android tidak efektif digunakan untuk meningkatkan pemahaman siswa kelas VI tentang konsep lingkaran.

\section{Uji Coba Luas}

\section{a. Analisis Deskriptif}

Hasil analisis deskriptif uji coba skala luas dapat dilihat pada tabel berikut.

Tabel 4. Deskripsi Data Uji Coba Luas

\section{b. Uji t}

\begin{tabular}{|c|c|c|c|}
\hline & & Nilai Pre-test & Nilai Post-test \\
\hline $\mathrm{N}$ & Valid & 146 & 146 \\
\hline Mean & & 41.05 & 80.99 \\
\hline Median & & 40.00 & 80.00 \\
\hline Minimum & & 13 & 40 \\
\hline Maximum & & 80 & 100 \\
\hline Sum & & 5993 & 11824 \\
\hline
\end{tabular}

Uji t pada uji coba secara luas menggunakan Independent Paired Sampel t test. Independent Paired Sampel t test atau uji t paired bertujuan untuk mengetahui perbedaan rata-rata dua sampel yang saling berpasangan atau berhubungan. Hasil uji t paired dapat dilihat pada tabel berikut.

Tabel 5. Uji Paired Samples Test

Paired Samples Statistics

\begin{tabular}{llllll}
\hline & & Mean & $\mathrm{N}$ & Std. Deviation & Std. Error Mean \\
\hline \multirow{2}{*}{ Pair1 } & Nilsi Pre Tes & 41.05 & 146 & 12.756 & 1.056 \\
& Nilsi Post-test & 80.99 & 146 & 10.892 & .901 \\
\hline
\end{tabular}

Paired Samples Test

\begin{tabular}{|c|c|c|c|c|c|c|c|c|c|}
\hline & & \multicolumn{5}{|c|}{ Paired Differences } & \multirow{3}{*}{$\mathrm{T}$} & \multirow{3}{*}{ Df } & \multirow{3}{*}{$\begin{array}{l}\text { Sig. (2- } \\
\text { tailed) }\end{array}$} \\
\hline & & \multirow[t]{2}{*}{ Mean } & \multirow{2}{*}{$\begin{array}{l}\text { Std. Devi- } \\
\text { ation }\end{array}$} & \multirow{2}{*}{$\begin{array}{c}\text { Std. Error } \\
\text { Mean }\end{array}$} & \multicolumn{2}{|c|}{$\begin{array}{c}95 \% \text { Confidence Interval } \\
\text { of the Difference }\end{array}$} & & & \\
\hline & & & & & Lower & Upper & & & \\
\hline Pair 1 & $\begin{array}{l}\text { Nilai Pre-test - } \\
\text { Nilai Post-test }\end{array}$ & -39.938 & 15.604 & 1.291 & -42.491 & -37.386 & -30.926 & 145 & .000 \\
\hline
\end{tabular}

Tabel 5 menunjukan nilai rata-rata untuk dua sampel terdapat perbedaan dari pretest sebesar 41,05 dan post-test sebesar 80,99. Nilai t-hitung sebesar -30.926, karena nilai post-test lebih besar dari pada pretest sehingga t-hitung menjadi negatif. Maka t-hitung atau -30.926 sama dengan 30,926. Sedangkan t-tabel dengan $\mathrm{df}=145$ sebesar 1,9765 maka t-hitung $>\mathrm{t}$-tabel atau 15.750 $>$ 1,9765. Karena t-hitung $>$ t-tabel, maka $\mathrm{H}_{\mathrm{o}}$ ditolak dan $\mathrm{H}_{\mathrm{a}}$ diterima. 


\section{c. Uji N-Gain}

Uji gain ternormalisasi (N-Gain) dilakukan untuk mengetahui peningkatan pemahaman siswa setelah diberikan perlakuan yaitu penggunaan e-modul interaktif berbasis android. N-Gain merupakan perbandingan skor gain aktual dengan skor gain maksimum. Adapun hasil uji N-Gain pada data hasil uji coba produk secara luas dapat dilihat pada tabel berikut.

Tabel 6. Hasil Uji N-Gain Uji Coba Luas

\begin{tabular}{ccc}
\hline No & Nilai & Kelas \\
\hline 1 & N-Gain & 0,66754 \\
2 & Kriteria & Sedang \\
3 & N-Gain \% & 66.754 \\
4 & Tafsiran & Cukup efektif \\
\hline
\end{tabular}

Berdasarkan data tersebut, hasil perhitungan gain adalah sebagai berikut:

1) Nilai gain ternormalisasi atau N-Gain sebesar 0,66754 yang diperoleh dari perbandingan skor gain aktual dengan skor gain maksimum. N-gain sebesar 0,66754 diinterprestasikan dalam katagori sedang dalam rentang $0,7>\mathrm{g} \geq 0,3$. Artinya bahwa terdapat peningkatan pemahaman siswa tentang konsep lingkaran dengan kategori sedang.

2) Nilai N-Gain \% diperoleh dari nilai N-gain dikalikan 100\% sehingga hasil N-Gain persen sebesar 66,574 yang ditafsirkan dalam katagori cukup efektif. Artinya bahwa penggunaan emodul interaktif berbasis android cukup efektif digunakan untuk meningkatkan pemahaman siswa tentang konsep lingkaran siswa kelas VI SD.

\section{PEMBAHASAN}

Berdasarkan hasil analisis deskriptif pada uji coba produk terbatas diperoleh hasil bahwa nilai pretest pada kelas kontrol dan kelas eksperimen mempunyai nilai rata-rata yang hampir sama, sehingga menunjukan bahwa kemampuan kedua kelas adalah sama atau seimbang. Sedangkan nilai post-test kelas eksperimen lebih tinggi dari pada kelas kontrol. Pada kelas kontrol pembelajaran tanpa menggunakan bahan ajar Matematika e-modul interaktif berbasis android dan pada kelas eksperimen menggunakan bahan ajar Matematika e-modul interaktif berbasis android. Hal ini berarti penggunaan bahan ajar Matematika e-modul interaktif berbasis android mampu meningkatkan pemahaman konsep lingkaran siswa kelas VI SD.

Hasil uji t pada ujicoba terbatas nilai t-hitung $>$ t-tabel $(6,340>2,0017)$. Sehingga Ho ditolak dan Ha diterima. Artinya terdapat peningkatan pemahaman siswa kelas VI tentang konsep lingkaran dengan pembelajaran menggunakan e-modul interaktif berbasis android. Hasil uji N-Gain sebesar 0,6744 diinterprestasikan dalam katagori sedang sedangkan nilai N-Gain \% sebesar 54,1603 yang ditafsirkan dalam katagori cukup efektif. Artinya bahwa penggunakan e-modul interaktif 
berbasis android cukup efektif untuk meningkatkan pemahaman konsep lingkaran siswa kelas VI SD.

Hasil uji coba terbatas juga sama dengan uji coba luas produk e-modul interaktif berbasis android nilai N-Gain \% diperoleh dari nilai N-gain dikalikan 100\% sehingga hasil N-Gain \% sebesar 66,574 yang ditafsirkan dalam katagori cukup efektif. Artinya bahwa penggunaan emodul interaktif berbasis android cukup efektif untuk meningkatkan pemahaman konsep lingkaran siswa kelas VI SD dalam skala luas.

Hasil ini sesuai dengan pendapat Daryanto (2014) tentang pembelajaran efektif sebagai berikut: 1) pembelajaran berpusat pada siswa; 2) melibatkan keterampilan proses sains dalam mengkonstruksi konsep, hukum atau prinsip; 3) melibatkan proses-proses kognitif yang potensial dalam meransang perkembangan intelek, khususnya keterampilan berfikir tingkat tinggi siswa; dan 4) dapat mengembang karakter siswa ${ }^{14}$. Pengembangkan e-modul berbasis android, dapat diakses atau dapat dibuka dengan menggunakan smartphone, tablet, komputer PC dan semua media berbasis sistem operasi terutama android. Sehingga siswa dapat membuka dan menggunakan e-modulini tidak hanya terbatas pada ruang dan pertemuan di kelas saja, tetapi dapat mempelajari dimana pun, kapan pun dan dengan siapa saja. Spesifikasi e-modul yang dihasilkan dalam penelitian pengembangan ini berupa modul elektronik interaktif Matematika materi lingkatan kelas VI SD. Modul elektronik ini merupakan paket pembelajaran individual yang berfungsi sebagai suplemen pembelajaran.

Penyusunan modul elektronik ini dilakukan secara sistematis, operasional, terarah, dan disertai dengan panduan petunjuk penggunaan bagi guru. Dengan demikian modul yang dikembangkan ini memiliki spesifikasi sebagai berikut: 1) modul elektronik ini dirancang secara sistematis dan materinya disusun sesuai dengan kebutuhan dan karakteristik siswa; 2) menggunakan kalimat sederhana dan jelas sehingga mudah dipahami serta memiliki tingkat kesukaran yang disesuaikan dengan pengetahuan sisw; 3) modul elekronik ini didesain/dirancang untuk meningkatkan pemahaman konsep lingkaran dalam pembelajaran melalui desain pesan (tulisan maupun gambar) semenarik mungkin; dan 4) dapat dipelajari oleh siswa menurut waktu dan tempat yang dipilihnya, dan dapat digunakan untuk belajar secara mandiri maupun berkelompok.

Modul elektronik memiliki kelebihan seperti 1) dapat diintegrasikan dengan internet, jika menggunakan aplikasi yang mendukung; 2) dapat langsung memutar video dan musik dalam aplikasi tersebut. Maka dapat dikatakan bahwa penggunaan modul elektronik sangat efektif untuk meningkatkan motivasi belajar siswa. Siswa menjadi tidak bosan belajar Matematika karena siswa dapat menjelajahi setiap materi menggunakan smartphone mereka. Ketika bepergian sekali pun, siswa

${ }^{14}$ Daryanto, Pendekatan Pembelajaran Saintifik Kurikulum 2013 (Yogyakarta: Gava Media, 2014). 
masih tetap bisa untuk membuka modul elektronik tersebut untuk belajar. Oleh karena siswa termotivasi untuk belajar, maka hasil belajar siswa pun akan meningkat

Edi Wibowo \& Dona Dinda Pratiwi (2018) telah melakukan penelitian yang menunjukan bahwa nilai kelayakan oleh ahli materi mendapat skor rata-rata 3,23 dengan kriteria baik dan nilai kelayakan oleh ahli media dengan skor rata-rata 3,28 dengan kriteria sangat baik, sedangkan nilai kelayakan oleh ahli bahasa mendapat skor rata-rata 3,02 dengan kriteria baik. Respon peserta didik sangat menarik, dengan pencapaian skor rata-rata 3,33 uji coba kelompok kecil dan pencapaian skor rata-rata 3,49 uji coba lapangan, respon uji coba guru sangat menarik dengan pencapaian skor rata-rata 3,64. Ini menunjukkan bahwa e-modul dengan menggunakan aplikasi Kvisoft Flipbook Maker yang dihasilkan dalam penelitian ini dianggap layak untuk digunakan dalam pembelajaran Matematika materi himpunan ${ }^{15}$.

Penelitian senada oleh Ula \& Fadila (2018) dengan hasil peneltitian diperoleh data penilaian ahli materi terhadap media pembelajaran ini termasuk dalam kategori "Valid" dengan nilai rata-rata sebesar 3,46. Penilaian ahli media terhadap e-modul ini termasuk dalam kategori "Valid" dengan nilai rata-rata sebesar 3,66. Penilaian ahli bahasa terhadap media ini termasuk dalam kategori "Valid" dengan nilai rata-rata sebesar 3,6. Pada uji coba skala kecil yang diikuti oleh 10 peserta didik kelas VII memperoleh skor rata-rata yaitu 3,65. Berdasarkan hasil dari angket respon yang telah diisi oleh peserta didik, hasil ini menempatkan e-modul pada kriteria "Sangat menarik". Pada uji coba lapangan skala besar yang diikuti oleh 30 peserta didik skor rata-rata kemenarikan yang diperoleh yaitu 3,55 pada kriteria "Sangat menarik"16.

Berdasarkan hasil penelitian dan pembahasan maka dapat disimpulkan bahwa penggunaan bahan ajar Matematika e-modul interaktif berbasis android dapat meningkatkan pemahaman siswa tentang konsep lingkaran. Artinya hipotesis yang menyatakan penggunaan bahan ajar Matematika e-modul interaktif berbasis android dapat meningkatkan pemahamn siswa kelas VI tentang konsep lingkaran terbukti.

\section{SIMPULAN}

Berdasarkan hasil penelitian dan pembahasan dapat disimpulkan bahwa bahan ajar Matematika e-modul interaktif berbasis android cukup efektif digunakan untuk meningkatkan pemahaman konsep lingkaran kelas VI Sekolah Dasar. Hal ini dibuktikan dengan nilai N-Gain

15 Edi Wibowo \& Dona Dinda Pratiwi, Pengembangan bahan ajar menggunakan aplikasi Kvisoft Flipbook Maker materi himpunan, Desimal: Jurnal Matematika, 1(2) 2018, 147-156. ISSN: 2613-9073

16 I. R. Ula, \& Abi Fadila, Pengembangan E-Modul Berbasis Learning Content Development System Pokok Bahasan Pola Bilangan SMP, Desimal: Jurnal Matematika, 1(2) 2018, 201-207. SSN: 2613-9073, Online ISSN: 2613-9081 
baik data uji coba terbatas maupun secara luas ditafsirkan cukup efektif. Hasil uji t pada uji terbatas dengan nilai t-hitung 6,340 dan t-tabel 2,0017 maka t-hitung $>$ t-tabel $(6,340>2,0017)$; dan uji coba secara luas nilai t-hitung 30,926 sedangkan t-tabel sebesar 1,9765; maka t-hitung > t-tabel atau $30.926>1,9765$, artinya ada peningkatan yang signifikan pemahaman siswa kelas VI tentang konsep lingkaran karena penggunaan bahan ajar Matematika e-modul interaktif berbasis abdroid.

\section{DAFTAR PUSTAKA}

Alismail, H. A., \& McGuire, P., 21 ${ }^{\text {st }}$ Century Standards and Curriculum: Current Research and Practice. Journal of Education and Practice, 6(6) 2015.

Cheng, S. F., Application of Creative Teaching. Hu Li Za Zhi The Journal of Nursing, 65(6) 2018, 4, https://doi.org/10.6224/JN.201812 65(6).01.

Daryanto dan Dwicahyono, Pengembangan Perangkat Pembelajaran. (Silabus, RPP, PHB Bahan Ajar), (Yogyakarta: Gava Media, 2014).

Daryanto, Menyusun modul, bahan ajar untuk persiapan guru dalam mengajar (Yogyakara: Penerbit Gava Media, 2013).

Daryanto, Pendekatan Pembelajaran Saintifik Kurikulum 2013 (Yogyakarta: Gava Media, 2014).

Desyandri \& Vernanda, D. 2017. Pengembangan Bahan Ajar Tematik Terpadu di Kelas V Sekolah Dasar Menggunakan Identifikasi Masalah. Dalam Seminar Nasional HDPGSDI Wilayah 4, 2017.

Hamdani, Strategi Belajar Mengajar (Bandung: Pustaka Setia, 2011).

Kariadinata, R., Kemampuan visualisasi geometri spasial siswa Madrasah Aliyah Negeri kelas X melalui sioftware pembelajaran mandiri. Jurnal Edukasi Matematika, 1 (2) 2010.

Majid, Abdul, Perencanaan Pembelajaran Mengembangkan Kompetensi Guru (Bandung: PT Remaja Rosdakarya, 2009).

Munadi, Yudhi, Media Pembelajaran: Sebuah Pendekatan Baru (Jakarta: Referensi, 2013).

Prastowo, Andi, Panduan kreatif membuat bahan ajar inovatif: Menciptakan metode pembelajaran yang menarik dan menyenangkan (Yogyakarta: DIVA Press, 2012).

Prastowo, Andi, Pengembangan Bahan Ajar Tematik: Tinjanan Teoretis dan Praktis (Yogjakarta: DIVA Press, 2014).

Sugianto, Modul Virtual: Multimedia Flipbook Dasar Teknik Digital. INVOTEC, Volume IX, No. 2, Agustus 2013: 101-116. https://ejournal.upi.edu/ index.php/invotec/article/viewFile/4860/3399

Sugiyono, Metode Penelitian dan Pengembangan (Research and Development), (Bandung: Alfabeta, 2016). 
Ula, I. R., \& Fadila, A., Pengembangan E-Modul Berbasis Learning Content Development System Pokok Bahasan Pola Bilangan SMP. Desimal: Jurnal Matematika, 1(2) 2018, 201-207. SSN: 2613-9073, Online ISSN: 2613-9081

Wibowo, E., \& Pratiwi, D. D., Pengembangan bahan ajar menggunakan aplikasi kvisoft flipbook maker materi himpunan. Desimal: Jurnal Matematika, 1(2) 2018, 147-156. ISSN: 2613-9073

Wiyani, Novan Ardy, Manajemen Kelas (Yogyakarta: Ar-Ruzz Media, 2013). 
Efektivitas Bahan Ajar E-Modul Interaktif Berbasis Android

232 | FENOMENA, Vol. 20 No. 2 (Juli - Desember 2021) 